\title{
Humour as an information-influencing resource in mass media
}

\author{
Liliya Duskaeva \\ Saint-Petersburg State University, Russia \\ 1.duskaeva@spbu.ru
}

\begin{abstract}
The purpose of this paper is to show how humour is involved in creating effective media communication. The research method is a stylistic analysis of the media text through establishing the manifestations of humour in its compositional components - paratext, metatext, and intratext. The paper reveals the manifestations of two types of irony-ridicule and banter - in these text components. It is established that banter is a means to demonstrate the event distantly, to reduce unnecessary pathos in the speech of top public officials, and to emphasize public contradictions indirectly. Language markers of banter are most often found in the metatext. In such forms of irony, veiled references and hints are expressed which require an additional cognitive effort to understand. The feelings that motivate irony are hidden behind a mask, and are the opposite of the implied ones expressed in the text: for example, indignation is hidden behind surprise and bewilderment. Banter is typical of business mass media, where every event is transmitted distantly. Ridicule is characteristic of sociopolitical mass media. It is expressed in the conflict charge of the media text - the desire to discredit the object of speech, and often acts as a means of transmitting alienation, demonstrating categorical opposition of one's position to another's. Ridicule is created by the saturation of negative-evaluative means, most often manifested in the expression of anger and indignation, which determine ridicule. The text markers of tonality, evaluation and degree of indirect expression form the basis of reading the modality character - i.e. badinage.
\end{abstract}

Keywords: mass media, paratext, metatext, intratext, ridicule.

\section{Problem statement}

A great number of pieces of research devoted to irony in the humanities indicate the constant interest of scholars in this complex and certainly understudied phenomenon. Considering the analysed literature, there is no complete line of ironic types, nor any accurate criteria of linguopragmatic classification of ironic types found in each language; there are searches of linguistic markers of irony in various languages and a complete list of illocutionary meanings in the Russian language does not exist, so the problem of ironic identification is still topical. The discussion on which elements of expression may serve as the signals of ironic intention is still 
going on. We believe that the approach to addressing the problem may lie within research on the use of irony in mass media.

The importance of resolving the question of how mass media influence a language is already recognized in the scientific sphere (see, for example, Duskaeva 2018; Perrin \& Cotter 2017). The study of the use of irony in this most rapidly developing area of communication will complement our knowledge of how irony adapts to it. In this article, we try to clarify the illocutionary varieties of irony relevant for the media and how to present them in paratext, metatext, and intratext. The purpose of the article is to clarify which forms of irony are involved in the fulfilment of communicative strategies of two important types of mass media sociopolitical and business. It will be shown how these forms are expressed in the paratext, metatext, and intratext of media texts.

The material for the analysis includes 150 texts from Russian newspapers and magazines of two types - sociopolitical (the newspapers "Novaya Gazeta" and "Pravda", and the magazine "Russky Reporter") and business (the newspapers "Kommersant", "Vedomosti", and the magazine "RBK") from 2015-2019. Without an opportunity to show the analysis of all the studied materials within one article, we are limited to the analysis of the most representative ones.

A truncated explanation of the background issue is necessary to show the peculiarity of research planning.

\section{The scientific context}

According to the studied literature, research on irony in the language of mass media has certainly been launched. The analysis of linguistic studies of irony in the language of mass media shows that its logic is defined with several vectors.

Firstly, there is interest in the development of typological specifics of irony functioning in various discourses. Paying attention to the specifics of advertising, radio, television, and newspaper discourses, researchers, as a rule, begin with distinguishing and clarifying typical illocutionary meanings of irony in these discourses and then advance to the means of their fulfilment. Secondly, different linguistic phenomena creating irony in different types of discourse are considered. Recently, attention is drawn from words and word combinations, creating, in some cases, a witty language play of compositionally designed speech units - ironic texts (Tsakova 2017; Vasileva 2017). In the media, it is the text that expresses the strategic communicative intention and purposes, so most authors' attention is not focused on the stylistic qualities of language units, but on the tools and means of design within the text. Thirdly, in some works devoted to the use of irony in mass media, along with the verbal means, attention is inevitably paid to the connection between verbal means and the bearers of ironic meanings of a different semiotic nature in media speech - caricatures, memes, and comics (for example, Grochala 2006, 2010; Kempa-Figura 2019).

Considering common research trends concerning the development of linguistic humour studies in mass media, we define the method of analysis. Firstly, referring to the specific object -Russian media discourse of sociopolitical and business (economic) newspapers - we follow the general logic of typological research on irony, which analyses the usage of the latter in various spheres of activity (for example, tourism, advertising, etc.). Sociopolitical and business (economic) mass media are different in terms of their use of irony. Based on the task set in the article - to clarify the illocutionary meanings of ironic types in mass media fulfilling various communicative strategies - it is important to find out the kinds of value-meaning content of irony in different types of media communication. 
Secondly, several pieces of contemporary research try to define the principles of connection between various elements in the ironic text. Following them, we try to understand how the expression of irony in the media of mentioned types is different. Thirdly, as other authors, we consider that mass media contain multicode, creolized texts, so the article pays attention to research on visual means participating in the creation of irony. The most important feature of research into the visual component is the recognition that the word meaning and image are integrated, making the complexly built sense (Chiara 2017; Popova 2018; Brzozowska 2013; Vasileva \& Duskaeva 2016). In our research, we consider those visual components that create the ironic effect when integrated with verbal components.

\section{Defining the approaches of the research}

To reach the research purpose of the article, irony in media discourse is considered in a specific way:

1. The ironic approach to the world is presented as the expression of the author's attitude (the author's subjectivity). As our analysis shows, the author's subjectivity (in some works, it is called the ironic modality) in media texts is expressed in a specific semantic feature of the text, which, as we have observed, is expressed with the means disclosing the abnormality - excess, discrepancy, logical contradictions, antinomy, etc., which are revealed to a different degree. It is abnormality that helps demonstrate the inconsistency of the surrounding reality. The character and degree of abnormality expression in different types of media text vary and depend on differences in the communicative strategy of the editions.

2. It is clarified how ironic texts participate in the fulfilment of communicative strategies in newspapers of different types: sociopolitical ones, with openly expressed subjectivity of the author, and business ones, where the author's subjectivity is eliminated. To ascertain the pragmatic conditions, the specifics of the comic linguistic expression must be considered in the materials from sociopolitical and business Russian newspapers from 2015 to 2019. These two traditional types of Russian mass media address different spheres of reality: political and economic. Each sphere is characterized by its type of activity (political or industrial), its range of active subjects, and the specific system of relationships between them.

3 . In the analysis, we shall take into consideration the interaction between various aspects of the humour media text composition, with three of them being the most important, in our opinion. The main one in the composition of the media text is the component which is called intratext. It reflects the news, i.e. the referent content of the text. Its structure is formed under the influence of existing professional traditions of creating "the accustomed performative actions, social relations in a certain cultural and historic moment" (Habermas 2009). It mostly reflects the development of the message proposition, which the author wishes to address to the audience. Furthermore, a specific aspect of informing through the channels of mass communication is that the message is formed within the intertextual paratext, which is set by the technical abilities of media, defining the development of the intratext. The text is supplied with images, infographics, sound, and visual accompaniment, if possible. So the paratext evolves not only in intertextual space (in newspapers - in the names of blocks, subblocks, infographics, and announcements of certain materials and future issues), but in intratextual space as well (as headings and subheadings, photos, photo comments, graphics, caricatures, etc.). It is the last mentioned that may become the bearers of ironic content.

The composition of media text is accustomed to the peculiarities of the future textual transmission through the channels of mass communication: the text is constructed in a form of communicative interaction with the audience. So, in the textual composition, the metatextual 
component deserves close attention, as it reflects the interaction of the author's position with the position of the other ("you", "he", "they", "I"). The metatext is a sort of a "frame", forming the usage of single words, word combinations, and sentences, aiding to transfer the information about the process of speech interaction of the author with the semantic positions of others. In linguistics, the said term was coined by Wierzbicka. Though she considered metatext as a superstructure of the text, "an extraneous body" (Wierzbicka 1978), our article explores metatext as a part of the inner semantic textual structure, without which the text cannot exist in media. The same position is followed, for example, by a Finnish researcher M. R. Luukka (quoted from Turunen 1999). The foundation for M. R. Luukka is the previous communicative experience and the predicted reaction of the addressee, which are the focus of the author's attention when creating the text.

Thus, there are three speech layers as the bearers of the ironic meaning in the linguocompositional organization: 1) paratextual, reflecting the interaction between this text and other elements within the complex of newspaper and magazine texts, 2) intratextual, reflecting its inner content, and 3) metatextual, expressing the intermediate position of the text in the feed of messages in mass communication. The latter performs the function of fastening all the components in a tight textual unity.

Let us turn to the materials' analysis.

\section{Irony as mocking social taints in sociopolitical mass media}

In sociopolitical editions, irony is presented in the form of tough, mean mockery. The dictionary definition helps in defining this modus. "Mockery" is defined as the expression of a cruel joke. To mock means to meanly and cruelly laugh at something or someone: "they laugh at something that is perceived as stupidity, absurdness, extravagancy, discrepancy, contradiction, lying, improvidence, inconsideration, awkwardness, or false judgments" (Arutunova 2007; Kornilova (Prokofyeva) \& Vasileva 2015). In the article, we would like to distinguish the specifics of appearance of illocutionary meanings of mockery in media, the source of which is irony.

In sociopolitical newspapers, the target for the author is the stupidity and unprofessionalism of management solutions, the red tape of bureaucracy, or the unkind treatment of people by authorities (the latter is especially common for oppositional periodical editions). Rapidly reacting to socially dangerous events, the author shows the imperfection of social structure and the taints of the existing political and bureaucratic system by means of irony.

The ironic meanings in media text are transferred in paratext, metatext, and intratext. The first inner layer - intratext - refers to a certain referent of the message. As in any complete text, the metatext is incorporated as a form of compositional-semantic entity into the paratext of a certain newspaper, supporting the unity of all the texts in the issue or a program. The plot of interaction between the author and the others is a specific metatext. It is important to define the leading principles founding the creation of this whole, and to distinguish the stylistic and semantic meaning mechanisms of the phatic material design in the text, constructed by means of irony.

As for the example, we analyse the article in "Novaya Gazeta" of April 28, 2019 "Truth in the eye" with the subtitle, revealing the content of the column: "Our life is such that it is time to forbid real news, not fake news".

\subsection{Paratext}

The author of the article is B. Bronstein, a columnist of an oppositional sociopolitical newspaper. The polemic, common for a sociopolitical newspaper, is in the headline. It is expressed partially 
with the contradictory conjunction ...not..., which helps the author to seemingly correct the creators of the law forbidding fake news. During the discussion on the law forbidding fake news, which is under consideration by authorities, an article with a polemic headline in an oppositional newspaper is inevitable.

The article is incorporated in the paratext of the newspaper with a particular "author's line", which places the author's photo, his name and surname, and the edition. We face a unique author's business card - it is a part of the paratext: it is put under the name of the block and separated from the text with a horizontal line.

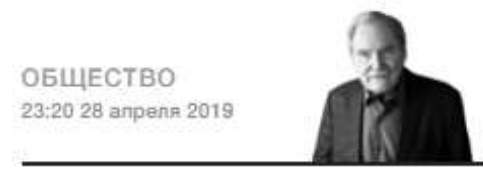

Борис Бронштейн

обозреватель "Новой

Figure 1. An example of the author's "business card" in the newspaper. Source: Novaya gazeta, 28.04.2019

The presence of the journalist's business card is significant: textually designed mockery is a phenomenon of the author's journalism, where the personality of the creator is extremely important. The author, with his clearly defined social position, is recognizable. His photo allows imitating direct communication with the reader, eye to eye, which elicits trust. But it is also the reason why the page may be considered part of the metatext, i.e. the text itself, because the business card "works" to set the dialogue relations between the communicants.

The caricature by Peter Sarukhanov that is above the text is the next component of the paratext.

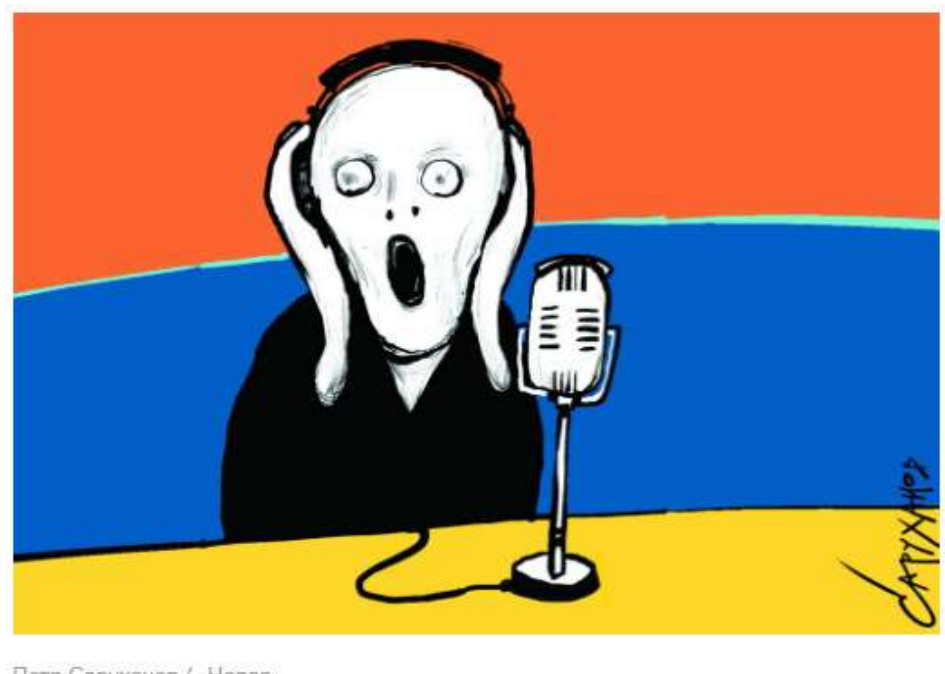

Figure 2. Caricature by P. Sarukhanov. Source: Novaya gazeta, 28.04.2019

The three-striped background of the caricature draws the reader's attention. It parodies the figure from the painting The Scream by Edvard Munch. The caricature of a man screaming in horror is added with the external attributes of a radio journalist who is shown at a desk with a microphone and headphones. The caricature of a journalist, feeling a high degree of horror and desperation, adds the ironic modality to the text. This hyperbolized image at the beginning of the text prepares the reader psychologically, hinting that they are about to read an article about something that is horrible in its absurdness. The means of abnormal expression is hyperbole. 
The main meaning load is certainly carried by the intratext.

\subsection{Intratext}

The referent basis of the article under discussion (B. Bronstein "Truth in the eye" Novaya Gazeta, 04/28/2019) is the messages from different newspapers about extremely absurd but real actions of the authorities. The article uses four such messages:

1) ... in the Mari city of Volzhsk, the arrested drunk hooligan fell off... the back door of the police car, but the policemen did not notice that and drove on (STRC Mari El. 04/25/2019);

2) ... the law forbidding fake news was accepted. ...it is in action: "Russia saw the law forbidding fake news for the first time";

3) two news headlines: "Nizhegorodsky teachers are paid extra money amounting to 1 rouble" and "In Kamchatka, the authorities want to prosecute a businessman for the debt of 1 kopek" and "...About the extra money for teachers in children's Balakirev musical school in Sarov mass media published the accounting lists and informed: "The sum of extra money ... is 1 rouble". ... at informational agency "Kam 24" disposal ("Kamchatka news");

4) ... the Senator of the Astrakhan region, Alexander Bashkin, called to actively fight the fake news in mass media.

This chain of messages reproduces real situations, which are connected cohesively by time and reason: in the author's opinion, they all appeared because of the extraordinary absurdity of the authorities' actions. The source of humour is the stupidity and negligence of those who must strictly follow the rules and exclude any violations. In these articles, humour is demonstrated with abnormality - alogism - of real actions of authority representatives.

In the first situation, the abnormality stripping humour of the situation - the negligence of the policemen performing their duty - is stressed with the semantics of contradiction, expressed with a contradictory conjunction but and a negative construction the policemen did not notice that, and drove on. The ironic effect is created with the situation itself, which shows the negligence of the policemen performing their duties, which is to protect people from extreme violation of the law.

In the second case, abnormality is found in the administrative courage of the authority representatives. Their actions are too energetic, which is not necessary, in the author's opinion: saw the law forbidding fake news for the first time.

In the third situation, abnormality is revealed in the absurdity of the actions of authority representatives who are ready to put in a lot of effort (which is stressed with a selection of verbs, naming the ministers' actions: the verb pay in the Present Simple passive tense, stressing the regular, repeated action, and the verb prosecute, pointing at the intensive action) for a small result - to pay extra money amounting to 1 rouble to teachers and to collect debts of 1 kopek.

The abnormality of the fourth situation described in the article is revealed in the fact that officials are ready to act with the violation of all laws to protect their interests.

The peculiarity of media text is that all the plots are published within the metatextual frame. The foundation of the metatext is the speech part (mask) of the narrator telling the four mentioned news stories. From story to story, the humorous modus of the metatext changes and reveals new meanings.

\subsection{Metatext}

\subsubsection{Irony of pretended mistrust}

Let us consider the example: 
What a nonsense: ...the arrested drunk hooligan fell off...the back door of the police car, but the policemen did not notice that and drove on. And this so-called news is spread by the so-called mass media on the so-called Internet, and then it is passed as flu-from mouth to mouth. OK, smart people will read and understand that someone made it up to draw attention to his newspaper or his site. But those who are stupid will believe it and think negatively about our police. As if they [police - L.D.] are not even able to lock the door of the car. Or to ask the arrested man to lock the door from the inside with a hook.

In this fragment, the humorous effect is made with the modus frame of pretended mistrust of the true primary message in mass media. This frame is formed primarily with reflexives - the means of evaluation of someone's speech, which express the attitude to the message as abnormal. The most important of them is the generalizing evaluative word nonsense, meaning "stupid, absurd, trifle, froth" (Efremova 2000). The word carries a powerful charge of doubt in truthfulness and authenticity. This charge is supported with the exclamatory particle what, and three repetitions of the word combination the so-called, which helps one sentence to be divided into three intonation parts. Certainly, the reader understands that such an extremely accentuated expression of doubt is pretence. Finally, all doubt disappears due to the imaginary argument between smart people, showing mistrust of the message in absurdity and those who are stupid: they will believe it and think negatively about our police. But the reader, understanding that the message describes absurd reality, can do nothing but "think negatively about our police".

And these ideas sound like open mockery at the inability of policemen. The first parcelling: As if they [police - L.D.] are not even able to lock the door of the car, which, again, reminds the reader of the inability of the law men to perform their protective function - this is the comic reality. The next parcelling (Or to ask the arrested man to lock the door from inside with a hook) increases the ironic nature of the situation. It draws an absolutely absurd situation, when the policemen ask the arrested man to lock himself in with a hook. The ironic logic of the narrative revealing the abnormality of someone's actions (nothing remains of the law offenders, unless they lock themselves up because of the law men's incompetence!) exposes the extreme professional inability of people in police uniform.

\subsubsection{Irony of pretended praise}

The example of pretended praise for the authorities' actions, which are not approved by the author, is: What can I say, the law forbidding fake news was accepted correctly and timely. The denotation of the message - the law forbidding fake news was accepted - is expressed with a generalized, personal sentence, carrying generalizing semantics into the expression. The adverbs correctly and timely contain the approval of the released law. But the sincerity of this approval is doubtful because the adverbial comment what can I say expresses the author's uncertainty about the possibility of the operation of law: And it seems to be in operation. The following narration repeats the inner dialogue of the praising person who starts doubting his high evaluation of the authorities, which supports the ironic modality. As if the narrator himself wants to dispel doubt: Well, here is the message under the headline: "Russia saw the law about fake news for the first time". The following question-answer complex contains open evaluation of law men, unable to seize the hooligan, when they are called slobs in police uniform. But the sarcastic logic of the ironic textual line is not limited to the demonstration of the incompetence of the policemen in carrying out their duties.

Then policemen will be shown in the situation that allows to demonstrate the administrative courage. For this, the author reminds the reader of the latest law forbidding fake news in mass media. The following fragment, designed in the comic frame, reveals the evaluation of the law in operation: I wonder who was the first to be caught? Is it the one who spreads nonsense about 
the slobs in police uniform? The question parcelling reproduces the dynamics of the author's thinking, as he "puts on" the mask of the authority's supporter. Continuing the pretended praise, the narrator is disgusted with the messages about careless and poor work of the policemen, calling such messages nonsense.

But, in the following fragment, everything changes and the ironic modus grows into the mockery modus. Multiple usage of antiphrasis in the metatext grows into sarcasm, which is increased in the demonstration of the abnormality of authority's behaviour from time to time.

\subsubsection{Irony of cruel joke}

Revealing the absurdity of the police actions in the following fragment, the author leaves no doubt as to their complete professional incompetence: No, under the new law, they prosecute the activist Elena Kalinina from Arkhangelsk, who placed information about the event on social networks... This protest manifestation was not approved, they say. In this case, the police considered the information to be fake and completed the report about Kalinina. After such an end to the story, the reader has no doubt that the author's true evaluation of the police officers is as the slobs in police uniform.

Then the metatextual frame is filled with the modus of cruel joke, when difficult refers to authority's actions that cannot be difficult at all. Completing the report is even harder than locking the door of the police car. Irony is provided in several places. On the one hand, we face the comparison between two logically different actions, considering the degree of their complexity. One of them is speech (completing the report) and the other one is action (locking the door). The abnormality of police's behaviour is illuminated more brightly from time to time, and mockery starts sounding like a cruel joke. The answer to the logically coming question Can these people do better in more complex circumstances, i.e. make a correct report, if they cannot perform an easy one? - is obvious: of course not. The police are poor actors who are not able to perform the simplest job functions. On the other hand, irony appears due to another reason: the discrepancy of the actions performed by the police and the ones they really must do. The sharpness of mockery is increased, as it is clear that the police officers succeeded in exactly these actions: but lately our police have got a good feel of these actions. The protest actions help the police be fit and not relax.

The metatextual frame of pretended praise for the police officers (constructed with the speech verb of the relative semantic would like to praise) includes other voices, which are introduced with speech predicates (prompt, here is the explanation): I would like to praise the police officers for something else, but they prompt me [as we see, someone's speech action is presented with a generalized personal verb in the plural] that, on the Internet, there appeared a video about the transportation of a hooligan from Volzhsk. It is clearly seen how... And here is the explanation of the MHA press agency in Mari El: while transporting... [another clarifying voice may be an official representative] What happens? It happens that it is not a fake, but true information. As we see, everything is clear now. The "other" voices testify that the messages about the nonsense in the country are true, though it is difficult to believe them.

\subsubsection{Irony of exposure}

Gradually, the metatextual frame returns to the route of discussion about fake and real news, but the anger of exposure stays in the metatext. It is "revealed" due to contradictory particles (really), the question-answer structure of the fragment "So who really is able to tell one from another in our reality? To the one who says that it is not difficult, I will offer two news headlines: 'Nizhegorodsky teachers are paid extra money amounting to 1 rouble' and 'In Kamchatka, the authorities want to prosecute a businessman for the debt of 1 kopek'". Both actions of the 
authorities - to pay extra money of 1 rouble and to prosecute someone for a 1-kopek debt cause mean mockery. The anger is read in the metatext and due to the game with antonymic definitions - fake and real: Which of the two news stories is fake? The first one? The second? Or both? However strange it may be, you are right: both news stories are real. Sarcasm is in the change of the metatextual dialogue with the reader brought into the game "guess what" due to the division of the question into parcelling (Which...? The first one? The second? Or both?), where there is nothing to guess about - the answer is obvious.

The metatext allows organizing the news paraphrase, which tells the reader about the documents issued by the authorities, but it retells the story through antiphrasis, continually increasing the sharpness of mockery: Well, it is at least justified somehow, although a little bit ill-considered. The antithesis justified, although ... ill-considered is the game because we cannot argue that the authority documents are proved or considered. It is more logical to add 1 dollar for international competitions. As for the 1-kopek debt, the information agency...has a copy... It says about the debt of 1 kopek for land rental ... And further-promise to pursue if not paid. What can we say? We should hope that the businessman Ivanov will take the warning seriously. Otherwise, I fear they will take him to court under arrest and will not set him free even with a bail of 2 kopeks.

The final metatextual generalizing thought of the journalist about how the government machine works in the country (That is how we live, that is how the government machine works with the doors swinging open in the process) contains irony. The situations presented in the publication build the whole picture of how the authorities work in the Russian state, which is stressed with the generalizing sentence: ...that is how the government machine works... The narration leads to the generalization of the exposing power when the doors swinging open in the process become the symbol of the authorities' inability in the country.

The mockery of recommendation in the final part of the publication sounds exposing: In this connection, it is better to forbid some real news. Irony lies in parcelling, informing the reader about the impossible desire of the official: Do not undermine and do not disturb. Senator Alexander Bashkin from the Astrakhan region called to actively fight against fake news in mass media...). Commenting on the phrase of the senator, the author makes his point: He should call to avoid true news, such as, for example, the fire in the territory of the rocket plant in Krasnoyarsk or the transit of our dreggy oil to Europe. Here is the danger to mislead "a vast number of people".

The question-answer complex at the end of the publication is filled with grief and despair, and shows the dead end of the dialogue between policy makers and the people (metonymically called millions): What will the millions think about billions which are spent on rockets and earned with oil? They will think that billions may burn, but nobody will pay us new ones. Despair is heard in the final phrase, which ironically uses metonymy of the quantifiers millions and billions. The first one refers to people, the second one - to money, but both are used without defining words, which stresses the insignificance of people for authorities.

Thus, mockery, which is common for sociopolitical mass media with their especially intense polemic, expresses a common strategy of opposition. The irony of exposure, created with the gradual dynamics from irony of pretended mistrust and praise to sarcastic irony, is directed against the home political enemy (especially in Russian oppositional political editions). The source of irony is the contradictions of reality itself: the absurdness of someone's actions, official zeal and political inability. Irony produces a satirical effect in these communicative situations where the author's position is claimed openly.

Irony takes another form in the communicative situations of other business editions. 


\section{Ironic badinage in business editions}

The specifics of the informative scenario in business editions is that the journalist prefers to speak not from their own viewpoint, but from that of an expert. All the news messages are toughly contradicted to the commentaries. But commentaries are also created with the extreme focus on personal peculiarities. Commentaries, evaluation, volitionality and other forms of speech subjectivity belong to experts and the journalist is responsible for the role of the media text creator - "frames" for the main text, which draw the lines for intertextual and intratextual connections in the textual structure. Certainly, in such conditions, there is no place for extremely obvious subjectivity; its author is hidden under the mask of irony. Mockery is revealed in the situations in which there is nothing funny in the reference; the commentator pushes some incompatible moments of the speech together, finding something funny in such a clash. This is the way pathos is decreased and an event describing a meeting of the most influential authorities may appear to be an ordinary fact of international life.

The basis for the ironic report is created by the type of the narrator, for whom irony is a way to present the events occurring in the halls of power. The type of the narrator allows him to doubt everything that the world powers speak about, and not to feel extreme respect toward them, but without expressing his position openly by mocking with mistrust instead.

Let us follow the creation of mockery in the "Kommersant" reportage: "Liberals of the sand careers" (Kommersant, No. 112 of 01.07.2019).

\subsection{Paratext}

On the newspaper page, the publication is introduced by an ironic photo of the President scowling and staring with mocking mistrust. The photo is already a mark of the modality of slight mockery, where the scowling forehead and grimly smiling, stretched lips of the photographic character testify to doubt and mistrust.

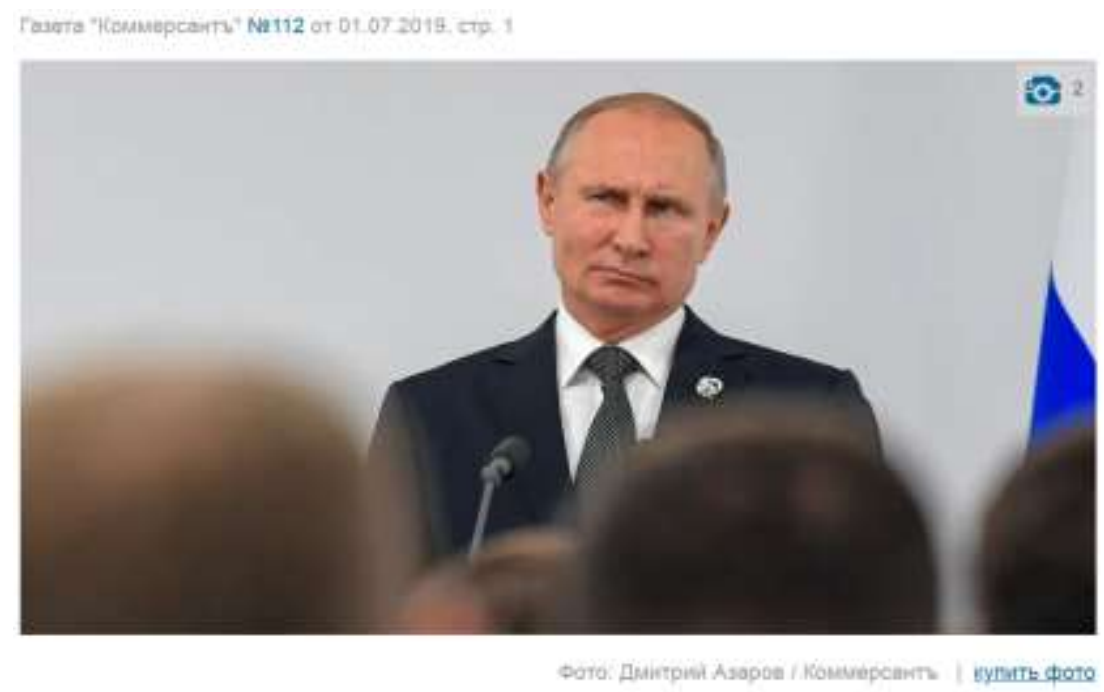

Figure 3. President of Russian Federation, photo by D. Azarov. Source: Kommersant, 01.07.2019

On the other picture, in the centre, there is one of the most influential oligarchs in Russia Leonid Mikhelson - greeting the Japanese partners. The smiles of the participants are open, creating the impression of their satisfaction. But the comment below the photo is coloured with 
the intonation of a slight smile. The image of Leonid Mikhelson and the partners' four crossed shaking hands contradicts the existing expression "I do not have four hands".

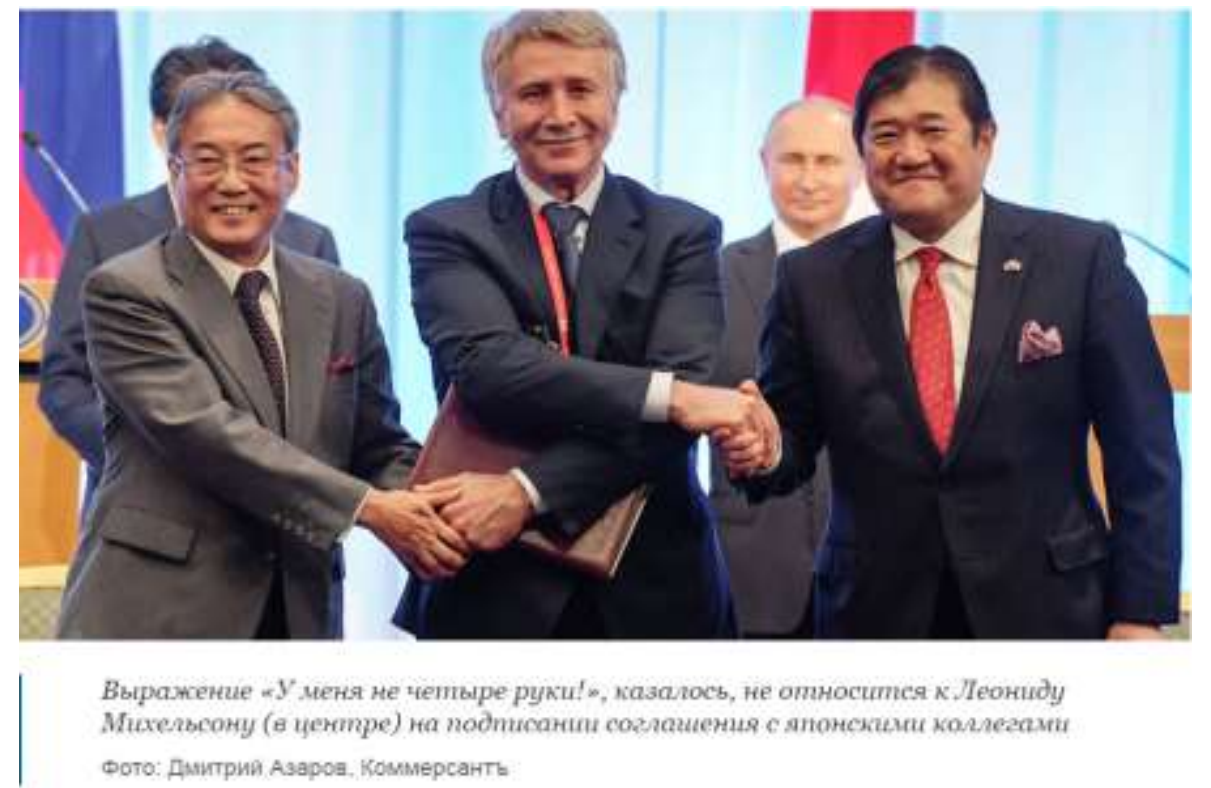

Figure 4. Photo "I do not have four hands" by D. Azarov. Source: Kommersant, 01.07.2019

The subheadlines of the publication are ironic. Anaphorically built in the narrating intonation, they comprise parallelism: How Vladimir Putin joined the struggle against the liberal idea and what it did to him; How G20 suffered from the typhoon of "two-siders"; How the meeting of G20 leaders finished in Osaka. The marks of irony in the first publication are: 1) phraseological units (joined the struggle against...) used in combination with the word idea (joined the struggle against the liberal idea and what it did to him), it obtains the meaning of an extreme hyperbole; 2) embodiment of the word (idea) in the result of its combination with the verb did (what it [the idea] did to him [to Putin]!). The violation of common ties between words leads to discrepancy of the content in the expression and the real order of things. In the second subtitle, irony is also present but this time because of hyperbole in the metaphor suffered from the typhoon of "twosiders".

The same modality is also expressed in the metatext, the ironic architecture of which supports the interest of the addressee and makes the reading entertaining. The latter is important because the publication is quite a long read.

\subsection{Metatext}

There are two speech subjects in the lead: the journalist, called to be the organizer of communication, introduces the narrator, Andrey Kolesnikov: Meanwhile the "Kommersant" special correspondent, Andrey Kolesnikov, having analysed this day of the President and learnt what was happening now in the Irkutsk region, draws an unexpected conclusion. Further, Andrey Kolesnikov leads the story. The journalist directs the speech polylogues and sets the order for different speech parts: the speech part of the journalist is framing, metatextual. Irony in the text body is polyvalent because the object of irony is the speech of the participants of the reproduced events. The responding, reacting irony of the narrator forms the frame of the metatext: all the side phrases are under the sharp and ironic focus of the reporter. 


\subsubsection{Ironic badinage about the weaknesses of someone's speech}

The ironic frame is created in the story about the meeting of Putin and Macron. The author ironically tells the reader about the attempt of the French President to show communicative politeness towards the Russian President with the demonstration of his knowledge of Russian greetings: The matter is not that he could say 'Hello!' in Russian. The irony is created with the denial of the significance of such a step from the side of the French President with the help of the denial construction introducing someone's speech. The denial allows enlightening the author's evaluation of Macron's start in communication with Putin, which, in the narrator's opinion, consists of Macron's desire to show off in all cases, including those that do not demand it. The abnormal absurdity of political speeches is pointed to with Macron's stretched redundancy, many times interrupted with introductory words: the main thing, in my opinion, is that the French President seems to have understood the interview of Mr. Putin in the newspaper 'Financial Times' and decided to argue with him about the death of the liberal idea, and the stylistic contrast of language means used in one expression. The following fragment contains bookish means in bold and the colloquial ones are underlined: In fact, he stands up for it on the side of the entire liberal world, where its ruin is still up in the air.

The means of ironic presentation of someone's speech is used many times. For example, it is used in the presentation of the German Chancellor Merkel's words as: Angela Merkel confessed to Vladimir Putin what she always confessed, which means that the Norman process must be continued and that "we support the regular and open exchange with each other, when we also speak about the differences in our opinions". The irony is caused by the absence of the result in the conversation between Putin and the Chancellor. The effect is created by the usage of the remark verb confess: this verb points at the special communicative scenario of the conversation - the story about what could not be said before (about a feeling, a sentiment). But the continuation of the remark contradicts the meaning of the word (confessed... what she always confessed). The manner of speech of the politician is shown ironically: in the given consequence of the subordinate object-clause sentences, the politician's words are expressed as if you do not understand which subordinate clause refers to which principal clause and which one "follows". The usage of the remark verb and the way of presentation of someone's speech parodies the typical way politicians talk uselessly about a topical urgent problem.

Putin's words are also ironic: In the protocol part of such a conversation, the answer is not demanded, but Mr. Putin had to deliver the speech, of course. But Putin's speech is also reproduced ironically: As if lulled by the consciousness of Emanuel Macron, meaning that he should not be bothered. We could say that such a tone suited night talk in a hotel, where the Russian President stayed before everybody goes to bed at last. But... The irony is created by the selection of vocabulary, which introduces Putin's speech - as if lulled-meaning that he should not be; by a tone that was suited to night talk in a hotel. The irony stresses the manner in which the Russian President negotiates.

\subsubsection{Badinage about someone's speech behaviour}

The characteristics given to the speakers by the author are as follows. The irony, for example, aims at the attempts of the young politician, Macron, to look more significant and older than he is. The irony is felt in the characteristics of the speech manner of the narration participants: it was unexpected; from an early time he claims the philosophical generalization at the level not below that of Jacques Chirac. The comparison of young Macron's speech with the speeches of Jacques Chirac - the long-liver of French political beau monde - in favour of the latter obviously hints at the young age of the acting French President. The comparison is further developed, and contextual antonyms stress the superiority of the one and the weakness of the other: But what 
Chirac made naturally - mister Macron seems to always make the strongest powerful rise, the outflow of which - it looks obvious - tires him very much. But Jacques Chirac was charged with it. And not only him... The comparison is stressed with predicates (made naturally - seems the powerful rise; tires - charged).

The comparison of Macron with experienced Chirac is not in favour of the younger man. The ironic badinage of the author about the new politician has the accent on the unpredictability of his speech behaviour: So, Emanuel Macron suddenly said, addressing Vladimir Putin: I am sure that, in the contemporary unpredictable world, liberal democracies have a lot to do and introduce... The abnormality of this behaviour is stressed with the violation in the rhythm of the narration, appearing due to the inverse usage of the particle suddenly. The narrator tries to explain his reproach further: It seems that Emanuel Macron was deeply impressed with the interview of Mr. Putin in the 'Financial Times' if he decided to impress Mr. Putin in his turn and so smartly: Russia only identifies itself, but with the liberal democracy, whatever Mr. Putin tells about it and about its ruin. The explanation is ironic (But only tries to identify, because it cannot be identified in fact) because it is built with a deliberate logical mistake - the "vicious circle" principle (explanation, defined with the inclusion of the primary thesis, which has to be defined).

\subsubsection{Irony as a hidden polemic on someone's position}

The narrative irony may conceal a hidden polemic on someone's positions. For example, in this text, there is polemic on the Western mass media, which regularly present the idea of political isolation of the Russian government. The narration proves the demand for Putin but it also says that casually. The effect of simplicity of the ironic narration is supported with the colloquial syntax in the form of incomplete sentences and unexpanded syntactical units. In the given case, we may speak about syntactically expressed abnormality - incomplete constructions. Ironic intonation penetrates through the text and, often, being a kind of the speech reportage strategy, replaces other types of evaluation: in this hotel people have still been waiting for Vladimir Putin. First - the Korean President Mun Chge In, the meeting with whom lasted until two in the morning. The story about the long wait of the completely free (and not demanded) chairman of the European Commission is ironic against the background of the extremely busy Putin:

In a dark hall of the hotel, the chairman of the European Commission Jean Claude Junker

was also roaming. He started playing the piano standing nearby (not for a reason) several times, regularly filled his glass with champagne and purposelessly wandered the hall, looking at rare faces kindly from time to time. But he was being demanded at last. The meeting with him also happened.

Irony is created with the usage of the chain of repeated verbs of continuous action (was roaming - started playing - filled champagne - looking at faces kindly - was being demanded). The meaning of slow movement without a certain direction is increased with the objects of repeated actions: also - several times - not for a reason - regularly - purposelessly - from time to time - the meeting with him also happened.

The ironic attitude to the position of the politician rushes even into direct speech, when the author uses the inserted construction creating abnormality with the interruption of smooth narration: I think that the dialogue between liberal democracies and countries they identify themselves with (Hey, where does that cruelty towards Russia come from? - A.K.) at least allows building and achieving much. The author's ironic inserted construction in the form of a question contains the main reproach to Macron, representing the liberal world.

Thus, Russian business editions have a tradition of ironic representation of the message about an event. The irony allows eliminating the subjectivity of the narration in accordance with 
the policy of the edition with the absence of frankness and indirect expressions. Due to the ironic modal frame, which allows separating ours from theirs, presenting the difference of the other and his semantic position in a mocking form, and expressing disagreement indirectly, irony can conceal the disagreement with someone's position in the subtext, hiding his attitude under the mask of irony. The ability of irony to express subjectivity indirectly is useful for the business press. Such an ironic form is another variant of the message about the event.

Besides, Russian press usually uses another form of telling readers about the participation of top public officials in some significant events - the reported narration about the actions of the country's or world's political elite; its feature is its solemnity, even pathos. The ironic message as an antithesis of the official report denies its traditions of covering the event. The modality that builds the ironic message "uncovers" the veil of solemnity. The ironic frame of the narration destroys the wall between the political elite and simple humans, created with the narration's pathos. The narration becomes entertaining because its smooth monotonous duration is refined with mockery, doubt, and argument with the stereotyped statements.

\section{Conclusion}

The analysis of the ironic speech activity differentiation in mass media shows that irony is used to focus the public opinion on the discrepancy and contradiction between social and speech acts and the common norm. The category that helps to transmit ironic meanings in the narration is abnormality, which is presented by a complex of various means and tools: contradictions, antonyms, hyperboles, litotes, alogisms, parodies, stylistic contrasts, syntactic incompleteness, interruption of smooth narration, interruption in the phrase rhythm, etc.

The types of ironic narration in media texts are created under the influence of the general communicative strategies of editions in which they are published.

For sociopolitical newspapers, the kind of irony that is typical has illocutionary power of revelation and mocking the negative sides of social life. In the inner paratext, the comic content is formed with photos, caricatures, newspaper page design, headlines, and text requisites on the page. The paratext, containing hyperbole, supports the modality of life's presentation that is worthy of mockery. These components create the "space" that starts forming the modality of contradictions. The social contradiction that becomes the source of humour is demonstrated in the intratext. The effect of exposure is reached through the irony of pretended praise and pretended mistrust, which are replaced with the irony of mocking, provided with a great number of means of open abnormal expression: hyperbole, absurdity, deliberateness, contradictions, alogisms, etc. Abnormality stresses the contradiction between what exists in real life (this is told in the intratext) and what the metatext describes. At last, the metatext brings together the process of speech influence of the author's "comic action" and the responsive perception of the reader.

In the business press requiring the means of objective narration, the comic method is irony, allowing to narrate indirectly without being in the midst of the event. Ironic illocution in such texts may be defined as badinage. The intratext does not contain any humour. An idea of ironic reinterpretation is expressed in metatextual structures, which are richly filled with the signs of speech interaction bearing humour. Badinage fills the metatext due to the signs of contradiction between the way one wants to express themselves and their appearance. Badinage is created with mockery over the manner of speaking and the content of political speeches. Such irony is created mostly in the paratext (in images, headlines, comments on photos) and in the metatext. The metatextual ironic frame allows separating "ours" from "theirs", distinguishing the "difference" of the semantic position. The text markers of tonality, evaluation and degree of indirect expression form the basis of reading the modality character - i.e. badinage. 


\section{Acknowledgements}

The study was carried out with the financial support of the RSF: grant 19-18-00530 "Humour as a communicative resource in the digital news environment".

\section{References}

Arutunova, N. D. (2007). 'Esteticheskii i antiesteticheskii aspekty komizma' [The aesthetic and anti-aesthetic aspects of the comic], in Arutunova, N. D. (ed.), Logical analysis of language. The linguistic mechanisms of the humour. Moscow: Izdatel'stvo «Indrik», pp. 5-17.

Brzozowska, D. (2013). 'Demotivators as a new type of media text' [Demotivators as a new type of media text]. Media Linguistics 2, pp. 124-126.

Chiara, B. (2017). 'Audiovisual Translation of Humor', in Attardo, S. (ed.), The Routledge Handbook of Language and Humor, New York, NY: Routledge, pp. 430-443.

Duskaeva, L. R. (ed.) (2018). Medialingvistika v terminakh i poniatiiakh. Slovar'-spravochnik [Medialinguistics in terms and concepts. A reference's dictionary]. Moscow: Flinta.

Efremova, T. F. (2000). Novyi slovar' russkogo iazyka. Tolkovo-slovoobrazovatel'nyi [The new Dictionary of Russian language. Explanatory and derivational]. Moscow: Russkii iazyk.

Grochala, B. (2006). Komizm jezzykowy w felietonach Antoniego Słonimskiego [Linguistic comedy in Antoni Słonimski's essays], Łódź: Drukarnia Cyfrowa I Wydawnictwo Pikor.

Grochala, B. (2010). 'Intertekstualność jako element budujący o zabarwieniu humorystycznym' [Intertextuality as a building element of humorous texts], in Mazur, J., Małyska, A. \& Sobstyl, K. (eds.), Intertekstualność we wspótczesnej komunikacji językowej, Lublin: Wydawnictwo UMCS, pp. 135-142.

Habermas, J. (2009). 'Lektsiia o zhiznennom mire' [A lecture on the living world]. Expert. Retrieved 10 October, 2013 from http://www.russia.ru/video/nauka_habermas/

Kempa-Figura, D. (2019). '(Internet-)mem kak novyi mediazhanr. Postanovka voprosa [(Internet) meme as a new media genre - an overview]. Media Linguistics 6 (1), pp. 80-89.

Kornilova (Prokofeva), N. \& Vasileva, V. (2015). 'Slang Toponyms and Newsmakers' Nicknames as a Communicative Contact and Indicator of Comic Culture in the Modern Russian Journalism. International Review of Management and Marketing 5 (Special Issue), pp. $1-10$.

Popova, T. I. (2018). 'Aktualnye napravleniia issledovaniia mediinogo internet-prostranstva' [Actual directions of the media internet space investigation]. Media Linguistics 5 (3), pp. 258-272.

Perrin, D. \& Cotter, C. (eds.) (2017). The Routledge handbook of language and media. New York: Routledge.

Tsakona, V. (2017). 'Genres of humor', in Attardo, S. (ed.), The Routledge Handbook of Language and Humor, New York: Routledge, pp. 489-503.

Turunen, N. (1999). 'Metatekst kak globalnaia sistema i voprosy konstruirovaniia teksta $\mathrm{v}$ posobiiakh po razvitiiu rechi' [Metatext as a global system and text design issues in the textbooks on speech development], in Kotyurova, M. P. (ed.), Stereotype and creativity in the text, Interuniversity collection of scientific papers, Perm: Perm University Press, pp. 310-320.

Vasileva, V. V. (2017). 'Anekdot v professionalnom mediatekste: pereprofilirovanie rechevogo zhanra' [Anecdote in a professional media text: repurposing the speech genre]. Media Linguistics 4, pp. 80-89.

Vasileva, V. V. \& Duskaeva, L. R. (2016). 'Kommunikativnyi stsenarii prizyva v massmediinom polikodovom tekste: proiavleniia ekstremistskogo vyskazyvaniia' 
[Communicative scenario of incitement in a plycode mass-media text: displays of extremist statements], in Kazanskii, N. N. (ed.), Acta linguistica petropolitana. Trudy instituta lingvisticheskikh issledovanii RAN [Works of Institute for Linguistic Studies of the Russian Academy of Sciences] XII, 3, Saint-Petersburg: Nauka Publ, pp. 395-405.

Vezhbitska, A. (1978). 'Metatekst v tekste' [Metatext in the text]. News of foreign linguistics 8. Moscow, pp. 402-421. 